\title{
THE ROLE OF JAWI TAFSIR IN SOCIO- CULTURAL TRANSFORMATION OF THE NUSANTARA ISLAM: A STUDY ON TARJUMĀN AL-MUSTAFĪD
}

\author{
D.I. Ansusa Putra, Zikwan \\ Universitas Islam Negeri (UIN) Sulthan Thaha Saifuddin \\ Jln. Jambi-Ma.Bulian, KM. 16, Simp. Sei. Duren, Ma. Jambi, Indonesia \\ Email : ansusa@uinjambi.ac.id, zikwansaleh3.zs@gmail.com
}

\begin{abstract}
Studies on Islam in Nusantara are primarily related to Islam's transmission to Nusantara. Meanwhile, the role of vernacularization (localizing) of Islamic sciences by Nusantara scholars - including attention to vernacularization of interpretive science - gained less attention. This paper employs the vernacular concept from A.H. Johns, discussing the role of Jawi Tafsir in the Islamization of Nusantara in the early phases of both the formulation of Islamic Nusantara Islam and the socio-cultural transformation of Nusantara. The conceptual frameworks are related to enculturation, adoption, and cultural adaptation, in which vernacularization occurs in each of these processes. Through studies on the Jawi's vernacular interpretation (Tarjumān al-Mustafid), this paper argues that in the early scientific formulation of the Nusantara Islam that transformed the socio-cultural Nusantara, Tarjumān al-Mustafid played a significant role. With another Jawi commentaries, Tarjumān al-Mustafid then became the Nusantara's Islamic identity and proof of Islam with the archipelago's character.
\end{abstract}


Keywords: Jawi Tafsir, Nusantara Islam, Tarjumān al-Mustafìd

\begin{abstract}
Abstrak
Perhatian para peneliti tentang Islam ke Nusantara sebagian besar terkait dengan transmisi Islam ke Nusantara. Sedangkan perhatian pada peran vernakularisasi ilmu-ilmu Islam oleh ulama Nusantara termasuk perhatian pada vernacularisasi ilmu tafsir masih terbatas. Makalah ini dengan konsep vernakular dari A.H. Johns, berfokus pada membahas peran tafsir Jawi dalam Islamisasi Nusantara dalam fase perumusan keilmuan Islam Nusantara awal dan transformasi sosialbudaya Nusantara. Artikel ini berfikir dalam kerangka konsep enkulturasi, adopsi dan adaptasi budaya. Di mana, vernakularisasi terjadi pada setiap proses tersebut. Melalui studi pada buku vernakular Jawi tafsir Tarjumān al-Mustafid, makalah ini berpendapat bahwa dalam perumusan sains awal Islam Nusantara yang mentransformasikan sosio-budaya Nusantara, keberadaan buku Tarjumān al-Mustafíd memiliki peran besar. Dengan buku tafsir Jawi lainnya, Tarjumān al-Mustafìd kemudian menjadi identitas Islam Nusantara dan bukti Islam dengan karakter Nusantara.
\end{abstract}

Kata Kunci: Tafsir Jawi, Islam Nusantara, Tarjumān al-Mustafìd

\title{
Introduction
}

Islamization of Nusantara is an important study of the existence of Islam in the study of the region. The urgency of this study related to the specific figures, events, products, and achievements that occurred in the past. Reconstruction of the entrance of Islam in Nusantara today has a role to find out the building and characteristics of Islam in the archipelago. There is a big mystery of discourse among scholars. The discourse is related to how the conversion of religions (from Hindu/Budha to Islam) in the archipelago occurred massively and without any violence. 
However, most researchers only discuss the process of transmitting Islam in the Nusantara and its transformation (Islamization). (Azra, 1992) (Syed Nuqaib Al-Attas, 1968) Several researchers mention the stages of Nusantara Islamic scientific formulation. It has become advanced stage of the transmission process by Arab preachers in the Nusantara areas. The transmission is the first step in the formation of a cultural transformation of the Nusantara. (Mustaqim, 2017) As Abdul Mustaqim says that the transmission of Islamic intellectuals from Arab to the Nusantara was a cultural transformation. (Mustaqim, 2017) Like (Azra, 1992) (Syed Nuqaib AlAttas, 1968), who discussed a lot about the entrance of Islam into Nusantara also illustrates how Islamic scholarship took the main role through network of Nusantara scholars.

Peter Riddell's research, for example, explains the process of transmitting Islamic teachings and Islamic science by connecting it with Islamic trends that happened in the Middle East from the $16^{\text {th }}$ century to the $19^{\text {th }}$ century. (Riddle, 2013) On the other hand, Azra's research ismore focused on studying intellectual networks in the context of teacher-students and their effects. (Azra, 1992) Although Peter Riddell has provided important maps of Islamic scientific works in Nusantara from the $16^{\text {th }}$ century to the $19^{\text {th }}$ century, Riddell focused his studies on the process of transmitting Islamic thought and teachings from Arab to the Nusantara. (Riddle, 2013) This can be understood from Riddell's conclusion that the influence of Muslim Nusantara Islam works - especially in the field of Sufism and the interpretation of the Quran- in line with scientific discourse and development of traditions happened in the Middle East, responses and transmissions. The Riddell's and Azra's works, are still focused on researching the 
process of islamization in Nusantara. This ensures that the research related to the formation of Nusantara Islamic Science has not been found before.

A.H. Johns (1988) divided the process Islamization of Nusantara into three stages: first, the transmission of Islamic values to Nusantara culture; second, the formulation of Islamic science in the Nusantara; the last, the transformation of Nusantara socio-cultural. These stages are connected to one another. An important component that connects this stages is the Tafsir. Because, Tafsir is an early Islamic Science which was introduced in the earliest of the Nusantara Islam. (Gusmian, 2010) Whereas, Tafsir Jami' al-Bayan fi Tafsir al-Quran by Al-Thabari, Tafsir Anwar by Baydowi and Tafsir Jalalayn known as the early period Tafsir, have been studied and delivered by Nusantara ulama to the public through their Tafsirs.

Vernacularization of Islam means translation of books on Islam into regional languages and using Arabic letters form to a new script called the Jawi script. Some areas in Sumatera refer to it as Malay Arabic script. (Fathurahman, 2014). One of the Tafsir with this Arabic Malay or Jawi script is Tarjumān al-Mustafìd written by Abdur Rauf Singkil from Aceh, which was later debated by some researchers about the originality (Riddle, 2013). However, the works of interpretive Tafsir using the Jawi script have become a medium for accelerating Islamization as well as an important element of socio-cultural transformation of the Nusantara.

Islamization of the Nusantara cannot be separated from the development of Islamic scholarship in the Nusantara and it has close relationship with the Jawi Tafsir. (Gusmian, 2010) (JOHNS, 1998) in his vernacular theory, noted that at the end of the 16th century AD in 
various regions of the Nusantara there had been a process of discussing Islamic vernacularization. (JOHNS, 1998) This can be seen through three phenomena. First, the use of Arabic script in Malay is called the Jawi script. Second, the number of absorption words from Arabic that have been transformed in local languages. Third, many literary works inspired by Arabic and Persian literary models. (Fakhriati, 2016) There is one more thing not mentioned by Johns, is the absorption of linguistic and grammatical rules and structures in Arabic. This opinion also supported by Syed Naquib al-Attas (Al-Attas 1995: 11) in Historical Fact and Fiction, that the use of jawi script in the Nusantara was in line with the spread of Islamic.

Even though A.H. Johns expresses the vernacular theory with regard to the existence of Jawi Tafsir, but he mentions that the Jawi Tafsir is a process of adaptation of Arabic terms to the Indonesian form. In contrast to A.H. Johns who stated that there was an absorption of Arabic ideas and terms in Jawi Tafsir, this paper would argue that Jawi Tafsir, specifically through Abdur Rauf Singkil's Tarjumān alMustafid, had contributed to Islamic scientific formulation with the distinctiveness of the Nusantara, although it remained through vernacularization in the lingua franca Nusantara; Malay language. The formulation of Islamic scholarship typical of the Nusantara then became the identity and trigger for the occurrence of socio-cultural transformation in the Nusantara community. Therefore, this paper will explain the vernacularization of Islam and Jawi Tafsir at the beginning, followed by the discussion of the Tarjumān al-Mustafid which is evidence of the main arguments of this paper. The findings will be a sub-topics before the conclusion which see the Tafsir Jawi has a distinctive characteristic and becomes the Islamic Archipelago identity. 


\section{Vernacularization Islam and Jawi Tafsir}

The existence of vernacularization Islam can be traced through the early works of Nusantara scholars, like Hamzah Fansuri, Nuruddin alRaniri, Yusuf al-Makassari, Abdussamad al-Palimbani, and Arsyad alBanjari. They have practiced the interpretation of the Quran as outlined in the form of shair, fiqh, history and others. It should not be wrong to apply such a rule based upon generalization to the religious (Islam) domain of Malay literature such as Religious law and jurisprudance and philosophy and mysticism. (Syed Nuqaib Al-Attas, 1968) Here, Interpretation studies do not only occur in the context of the commentary, but also in the practice of interpretation.

There are only a few completed Jawi Tafsir in Nusantara. Tarjumān al-Mustafíd is the first fully Jawi Tafsir in the Nusantara. But Tarjumān al-Mustafid is not the first al-Quran interpretation, from the practice of interpretation. Because previously there had been several interpretations, although not as a whole, as in the verses of the poem Hamzah Fansuri. (Rippin, 1988) Interpretation here in the widest mean. That is the whole practice of understanding the al-Quran as outlined in the form of works, such as poetry, jurisprudence, understanding verses, and others. At least in the context of Islamic scientific formulation as understood by Riddell. Riddell on his work entitled Malay-Indonesian World: Transmission and Responses, stated the controversies in Qur'anic exegesis and its relevance to the MalayIndonesia world. He then revealed the influence of the development of the Qur'anic world of interpretation in the Muslim world in the dynamics of Islam and Muslims in the Nusantara. (Riddle 2013: 27-30) 
Consequently, the universal principles of Islam were vernacularized in specific time and space, and contextualized or localized forms and expressions of Muslim piety emerged in these regions. Owing to the regional geographical and cultural variations, diverse manifestations of Islam in the form of beliefs, thoughts and practices can be seen in these regional settings. The indigenous social and cultural traditions came to be well-reflected in the beliefs and practices associated with Islam. Thus, vernacularization Islam can be understood as a process through which the message and teachings of Islam adjusted and adapted in local regional environments, particularly in the non-Arab regions. The notion of 'vernacular Islam' does not deny the consistencies or universalist orientations in many Muslim beliefs and practices, which are practiced all over the globe with considerable similarity.

This happened because of the vernacularization practice. Then, the writing of Malay language with Arabic script was born. The choice of Malay is because Malay language is the lingua franca in the Nusantara Islamic scholarship (Syed Nuqaib Al-Attas, 1968) Vernacularization is a transmitting of vocabulary related to the phenomenon of religious teachings which initially used Arabic (alQur'an), then was replaced. translated and written in typical characters in the form of the language of the local community. In carrying out this practice of vernacularization is not only diverts from the aspect of language or its translation, but there is a process of processing various ideas in the form of language, tradition and culture in the local community so that something is permitted. So this is where the occurrence of the Arabic language has permeated the language of the local community. (Mustaqim, 2017) 
This idea of Islamic vernacularism is derived from the vernacular theory of A.H. Johns in his writing. AH. Johns wrote an article on Approaches to the Qur'an in Contemporary Indonesia entitled Qur'anic Exegesis in the Malay-Indonesian World: An Introduction Survey. From a number of papers, A.H. Johns studied generally relates to the interpretation of the al-Quran in Indonesia in the $17^{\text {th }}$ century AD (which is the interpretation of Tarjumān al-Mustafid) and the $19^{\text {th }}$ century AD (showing the interpretation of Marāh Labīd) by showing his method of interpretation and classical interpretation and the process of arabizing the use of terms in the context of language in the Nusantara.(Saeed, 2006)

The history of the interpretation in Nusantara has been recorded by Anthony H. Johns, It stated that at the end of the $16^{\text {th }}$ century AD there was much evidence of the process of vernacularization or discussion of the Islamic logic in various parts of Nusantara. This can be seen from the development of the phenomenon of religious vernacularism that has seeped in the text. (Saenong, 2006) Vernacular theorist A. H. Johns noted that at the end of the $16^{\text {th }}$ century AD in various regions of Nusantara there had been a process of Islamic vernacular which can be seen in three phenomena. First, the use of Arabic script in Malay is called the Jawi script. Second, the number of absorption words from Arabic that have been transformed in local languages. Third, many literary works inspired by Arabic and Persian literary models. (JOHNS, 1998) There is one more thing not mentioned by Johns, it is the absorption of linguistic and grammatical rules and structures in Arabic. this opinion was also supported by Syed Nuqaib al-Attas in Historical Fact and Fiction, he said that the use of Jawi 
script in Nusantara was in line with the spread of Islamic teachings. (Al-Attas, 1995)

Understanding vernacularization is often associated with the transmitting of vocabulary in a particular ethnicity. Here are the examples Vernakularisasi dalam Tafsir Nusantara: Kajian atas Tafsir Faid al-Rahmān written by KH. Sholeh Darat al-Samarani, and the work of Lilik Faiqoh and Mursalim, entitled Vernakularisasi alQur'an di Indonesia: Studi Kajian Tafsir al-Qur'an. All of the Qur'anic those scholarship articles are related to the reality of the vernacularization after the Islamization of the Nusantara occurred. Referring to Farid Saenong's Article in his interview with A.H. Johns, such vernacularization type is called vernacularization in a narrow sense.

This article is different from the researches above. This article sees vernacularization in the context of the Nusantara Islamization. Jawi Tafsir is a form of vernacularization in the process and stages of Islamization of the Nusantara. Wheres, this is also meant by A.H. Johns in his article Qur'anic Exegesis in the Malay-Indonesian World: an Introduction Survey. A.H. Johns surveyed and compared two Tafsirs that have different languages; Tarjumān al-Mustafìd in Malay and Marah Labid in Arabic. The theory of A.H. Johns vernacularization was occurs in the context of the Islamization of Nusantara.

Indeed, according to A.H. Johns, interviewed by Farid F. Saenong, vernacularization only occurs when ethnic language is used in interpretations. (Saenong, 2006) However, it does not explain the context when ethnic language is used. Vernacularization here is in the narrowest sense that is the translation/interpretation of the al-Quran 
from Arabic to ethnic language. Whereas vernacularization in the context of the Nusantara Islamization is wider than that. It was transmitting the religious teachings from the Arab region to the Nusantara using the language of instruction of the Nusantara (lingua franca); Malay Language.

The recognition of Malay as the lingua franca Nusantara has been explained extensively by Syed Muhammad Nuqaib al-Attas in his book The Origin of The Malay Sha'ir. Al-Attas mentioned that Hamzah Fansuri through his sya'ir was the first place to use Malay as the language of instruction (lingua franca) in Nusantara Islamic scientific. (Syed Nuqaib Al-Attas, 1968) Al-Attas in his theory also ensured that Hamzah Fansuri's personal contribution in the production of sya'ir was so arousing to the people that it could be accepted by the Islamic community of the Nusantara.

\section{Interpretation of Nusantara Ulama: The Tarjumān al-Mustafíd Case}

A.H. Johns said that in the Tarjumān al-Mustafid contains a reference in the history of Islamic science in Nusantara. It was contributed to the study of the Qur'anic interpretations in the Nusantara and laid the foundations for a bridge between translations and interpretations. (JOHNS, 1998) Tarjumān al-Mustafid is an interpretation of the Qur'an by Shaykh Abdurrauf As-Sinkili, which is considered as the first work written by local Nusantara scholars in the field of Tafsir. It is written in Malay, As-Sinkili tries to bridge the gap between Arab civilization and the intellectual world of MalayNusantara Muslims. Because at that time the Malay language became the lingua franca in Nusantara, in the field of inter-ethnic 
communication, correspondence, administration, scientific fields, and so on.

Tarjumān al-Mustafid is a Tafsir that emerged in the $16^{\text {th }}$ century by Abdurrauf as-Sinkili. It is very representative as an interpretation that influenced the formulation of Islamic science in the process of Nusantara Islamization. Based on the theory of A.H. Johns that Islamic vernacularization occurs in three aspects: first, vernaculate the Islamic teachings in form Nusantara language. It is undeniable that the Tarjumān al-Mustafid use local language in interpreting the al-Quran. In its interpretation, Abdurrauf as-Sinkili uses Malay language and not Acehnese as the local language. The choice of Malay language was motivated by the status of Malay language as a lingua franca of Islamic science during the Islamization of the Nusantara.

Vernacularization of Islam in the context of the Nusantara is inseparable from the existence of Malay as the language of instruction (lingua franca). As explained earlier that al-Attas explained the conception of Nusantara Islamization with the process of forming the Nusantara Islamic science through certain characters, works and patterns. Al-Attas always started his theory of Islamization from his studies of Hamzah Fansuri's Syair in many of his works. This is due to al-Attas's view of the conception of language. According to him language is very much related to worldview. So, the problem of language is also a problem about worldview. In the context of the Nusantara Islamization, al-Attas described the influence of language in contributing to the formation of Nusantara Islamic science. From his search, the Malay language introduced in Hamzah Fansuri's syair was the earliest work to see the worldview of Islam in the Nusantara. Thus, the relevance of the Malay language used in Hamzah Fansuri's sya'ir 
was closely related to the Nusantara Islamization. In this case, Malay language was named as the language of instruction (lingua franca) in the treasures of Islamic scholarship in the Nusantara. By itself, the early formulation of Islamic scholarship took place in the 16th century.

The use of Jawi (here and after referred to as "Melayu-Jawi") in this era increasingly found its strength, because Malay is a lingua franca used in the Nusantara and is the official language used in government communications, interstate relations, and trade. However, in a society where the local language is non-Malay, Malay-Jawi is of course only controlled by certain people, such as government, educated people and traders.

The tradition of writing Islamic scientific works in the Nusantara, such as in the fields of literature, fiqh, kalam, hadis, Tafsir and Sufism moved together with the introduction of Islam to the population in the Nusantara. Azyumardi Azra's study of the ulama network in the Nusantara with the ulama in the Middle East not only showed the strong links of the Nusantara Muslim intellectuals with the ulamas in the Middle East, which gave birth to the process of response and transmission of knowledge. On the other hand, the study also provided important data on Islamic works of the Nusantara Muslims in the 16th and 17th centuries in various fields. Hamzah Fansuri, Nuruddin arRaniri (d. 1658), 'Abd ar-Rauf as-Sinkili (1615-1693), Muhammad Yusuf al-Maqassari (1627-1699) were among the important figures who played a role in the tradition of writing works Islam in the Nusantara in various scientific fields is quite diverse.

Arabic which is the language of the Qur'an is taught by the preachers to the people of Nusantara. The introduction of Arabic script to Malay people through a process that is not short. In the $3^{\text {rd }}$ century 
Hijriyah Arabic script had been engraved on the tombstone in Kedah, which is a tombstone that reads the name Sheikh Abdul Qadir bin Husayn Shah Alam which dates to 290 H / 910 M. Sheikh Abdul Qadir was a Persian descendant. The discovery of the tombstone is proof that Arabic script in Arabic had existed in Nusantara in the 10th century $\mathrm{AD}$.

The $13^{\text {th }}$ century AD was an age of Islamic glory in Nusantara. The development of Islam has made Arabic get a place among adherents of Islam in this area. Old Malay language that uses Indian letters changes using Arabic letters. It is through this Arabic-Malay script and script that the preachers preached their writings in the Nusantara, so that the Arabic-Malay writing developed in such a way, both in the world of education and commerce. Another motive for the development of Arabic-Malay characters is because local people cannot speak Arabic, so they seek to combine local (Malay) language with Arabic in a writing. The one used to write is Arabic letters, while the language used is Malay.

It seems that the influence is Islamization with the use of Arabic script, although the adoption of Arabic into the Jawi has made many mistakes due to dialect differences. Therefore, the Malay text can be said as proof that the Jawi script has been used to write in the Nusantara, so the existence of the Jawi script has become a cultural symbol in this Nusantara.

The researchers were amazed at the uniformity found in Jawi's writings and spelling as written in manuscripts before the $17^{\text {th }}$ century AD written throughout the Nusantara. Actually, the uniformity of the writing was due to the writing skills at that time were only mastered by several scribes who had been trained in terms of writing rules so that 
uniformity could be maintained. This fact is reinforced by the fact that most of the texts at that time consisted of official religious and royal documents. The writing activity was of course only written by special groups such as palace writers, scholars, and teachers.

This is in line with the confusion of some experts regarding the time the Islamization of Nusantara began. Archeologically, tombstones have been found in Arabic since the $9^{\text {th }}$ century AD, but new Islam can spread in the $13^{\text {th }}$ century $\mathrm{AD}$. It can be explained that the process of transmitting Islamic teachings from Arabia to the Nusantara actually happened in the $9^{\text {th }}$ century AD. But Islam as a science with the character of the new Nusantara emerged in the $14^{\text {th }}$ century AD. This indicates the existence of vernacularization in the Tarjumān alMustafid in the context of Nusantara's Islamization.

Second, the absorption of Arabic in interpretation. Tarjumān alMustafid is intended to make it easier for Malay people to understand the contents of the al-Quran. Therefore, Abdurrauf occasionally absorbs the Arabic words to make it easier for readers to understand the textuality of the verses of the al-Quran. As-Sinkili gave Arabic codes in explaining several problems, the explanations completed with their own signs or codes. To explain about Qira'at, it is usually marked with "faidah" in parentheses. Faidah is absorbed from Arabic to make it easier for readers to understand the explanation. So, the word Faidah is a Malay language which means benefits, benefits, etc.

This can be seen from the explanation in surah al-Fätihah:

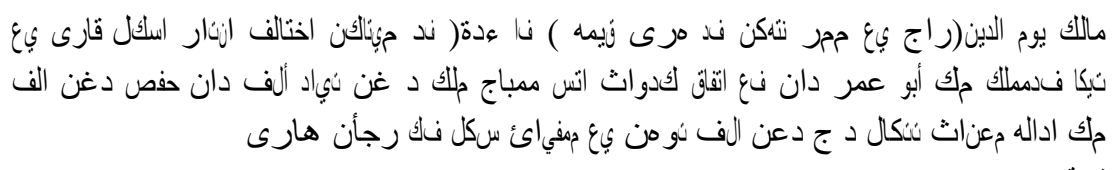


Maliki yaumiddin (the King who ordered on the Days of Qiyamat (faidah) to declare the ikhilaf between all three qori in 'malik' then amar abu with ittifaq both for reading 'malik' with no alif and hafad (kasroh) with alif then their meaning when ' $d$ ' " $j$ 'with alif god who has all the work of Qiyamat.

While the word Al-Qisah is also used in the Tarjumān al-Mustafid as a code in the explanation of the verses of the al-Quran. The word alQisah in parentheses serves as an explanation of Asbāb al-Nuzūl. The selection of the word al-Qisah as a code to explain the description of $A s b \bar{a} b$ al-Nuzūl is due to the Nusantara context, which is more familiar with the stories. While Asbāb al-Nuzūl is a terminology that is only understood by the scholars. Therefore, as-Sinkili uses the words 'alQisah' rather than Asbāb al-Nuzūl, history, etc.

The absorption of Arabic in the interpretation is one of the characteristics of the Tarjumān al-Mustafid because the explanation is short, solid, easy to understand and suitable for beginners.

Third, the absorption of the grammatical structure of Arabic in the constellation of Malay. Grammatical Arabic is widely used in the asSinkili Tarjumān al-Mustafìd. Especially in lexical grammatical forms (changes in word form). Whereas in the syntactic form (sentence) there is no absorption of the structure of Arabic sentences into Malay. This can be seen from the explanation regarding Surah al-Ikhlās:

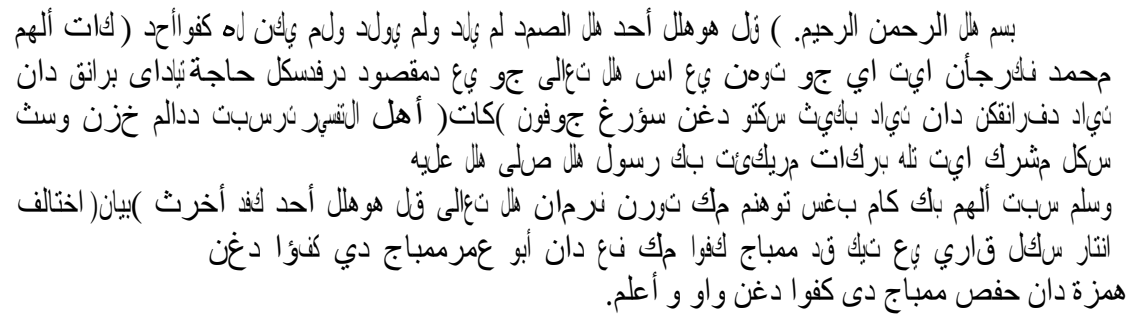




\begin{abstract}
Bismillāhirraḥmānirraḥim (Qul huwallāhu ahadu lillāhișșamadu lam yalid walam yūlad walam yakunlahu kufuwan aḥad)
\end{abstract}

Say O Muhammad that behavior 'ay' (Or; arab) is also the one god lillahi ta'ala. Also, means, from any necessity there is no power to bear, and there is no begottenness, and no partner for one with him. (words) ahlu the interpretation in Khazin (Tafsir al-Khazin) that all the polytheists have said they are worshiping god not the messenger of the Prophet (peace be upon him) then the word of Allah Ta'ala 'Qul huwallahu ahad until the end ..' (Bayan (Explanation) ikhtilaf among all the three qori who read the 'kufuwan', the fang and abu 'amar read in the 'kufuwan' with hamza and khofad (kasroh) read the kufuwan with waw, wallahu' alam.

The word 'musyrik' is the absorption of the grammatical structure on the lexical aspect. The word musyrik refers to the meaning of Arabic terms which means people who associate partners with Allah.

The Tarjumān al-Mustafid known as the most complete interpretation with Jawi has fulfilled the vernacular aspects in the theory of A.H. Johns. Vernacularization is intended as a way of formulating Islamic science. In addition, vernacularization is also intended to facilitate the reader of the interpretation in understanding the meaning and content of the al-Quran. This kind of vernacularization is also found in the works of Nusantara's ulama, such as: Hamzah Fansuri, Nuruddin al-Raniri, Syamsudin Sumatrani in various disciplines. 


\section{Jawi Tafsir and Transformation of the Nusantara Socio- Culture}

The use of Jawi is the main factor that accelerated the Islamization of Nusantara because Islamic teachings were written by Malay scholars using Jawi script so that the general public could read it and understand the teachings contained in it. There is a reciprocal relationship between Nusantara and Islamic languages. Whereas, Islam was a major factor in the rise of Nusantara language as a written language, because Jawi Script were used extensively in the sultanate countries of Melaka, Johor, Brunei, Sulu, Patani, Aceh, and Ternate in the early $15^{\text {th }}$ century for the purpose of correspondence, orders, and interconnection between lines in the port of Malaka. (KBBI, 2016) All texts are written in Jawi. Aksara Jawi is a tool in the gradation of Islamization in the Nusantara.

In the tradition of the Nusantara, the Jawi script is used to write down various things of the phenomenon of life so as to produce real work that is characteristic of traditional writing of the community in Nusantara. The work of the people of Nusantara in the past in the form of the writing of Jawi script which uses Malay is called the Nusantara script. The number of Nusantara manuscripts is innumerable because the search for them is still on going in various regions in this Nusantara. Nusantara manuscripts will not contribute to society now if they are not read and are not understood. In this connection, this article will examine the history of the existence of the Jawi script so that it is manifested and developed in the Nusantara. In addition, the role played by the script was also examined, especially in reading Nusantara texts which were one of the Nusantara's intellectual treasures. 
Interpretations in the Nusantara during the 17 th century AD were written in Arabic with Jawi script. This is possible, because based on the trace of Anthony H. Johns, as quoted above, at the end of the 16th century AD there had been discussions about the vocabulary of Islam in various regions of the Nusantara, as seen in the use of Arabic scripts which were then called Jawi scripts, and Pegon. (JOHNS, 1998)

Islam is very attached to Nusantara Culture, so it is very difficult to separate the two. The results of the transformation of Islam in Nusantara made Islam a feature of the Nusanatra people. This can be seen from the attitude and behavior of the Nusantara whose teachings are based on the basic teachings of Islam, namely the Qur'an and hadith. Islam has given universal values that are new and positive in the culture of the Nusantara so that Islam is considered a major component in the culture of the Nusantara. Likewise, the characters that are the link between the Malay community are also derived from Islamic teachings.

The Islamization of the Nusantara as a result of cultural transformation can also be seen from various indicators such as the language system, education system, beliefs, behavior and thinking. Given the breadth of indicators that indicate the transformation of the Nusantara Socio-Culture, all can be grouped into three major components; Culture, social change, and Islam.

Transmission and transformation in the study of sociology have relationships that cannot be separated from each other. Both are processes to lead to social-cultural change. Changes from the former do not yet know to have knowledge, changes that were not yet good to be commendable behavior, and the process of change and selfadjustment to be able to stay, mingle, and be accepted in society. Both 
meeting (transmission and transformation) in the history of the Nusantara can be traced from the writing of Islamic scientific works that have existed since the $12^{\text {th }}$ century AD. The author calls this stage a stage of Islamic scientific formulation in the Nusantara.

In the context of Islamization of the Nusantara, the stage of transformation of Islam in the Nusantara can be traced through expert studies related to the Islamization of Nusantara. Among them Coedes said that a hypothesis could be formulated that Islam had functioned as a force for socio-cultural transformation in the Nusantara. (Hasbullah, n.d.)

The indicators of Nusanatra's socio-cultural transformation can be seen in the centers of civilization circles in the three right points, namely Palace, Islamic Boarding School and Market. (Fadil, 1990) The palace as the center of power plays a role in the field of politics and structuring of social life. Here with the support of scholars who are directly involved in the government bureaucracy, Islamic law is formulated and applied. Here also the book of history is written as the basis of legitimacy for Muslim rulers. Islamic boarding schools play a role in the education sector, and are the second cultural center after the palace. Here networks of religious studies in the wider community are built, in the city or even in the countryside, as well as the themes of recitation. Here also the religious books are written and copied to be distributed. The role of pesantren, or dayah and meunasah in Aceh, surau in Minangkabau, became more prominent in the 18th century $\mathrm{AD}$ in all corners of Nusantara, (Putra, D.I. Ansusa, 2019) He also acts as a center for Sufi tariqat activities. This institution which was originally regional in nature developed into a supra-regional institution whose leadership and students were no longer based on ethnicity. $\mathrm{He}$ 
grew into a universal institution that accepted teachers and students regardless of ethnic background and area of origin. At that time the pesantren or dayah were able to form a network of intellectual leadership and the spread of religion in various levels and between regions. (Azra, 1999)

While the market plays a role in the field of economy and trade, it also serves as. a residential area of merchants, educated people and other middle classes, including artisans, who face directly the developing cultural situation. Here people from different ethnicities and different races meet and interact, and exchange ideas about trade, political, social, and religious issues.

In addition, the presence of Islam in the midst of Indonesian society is not only a religious system, but at the same time an alternative force that is quite calculated. Islam is a force broken for followers to destroy the unequal social order. Islam is also a force in liberating the nation from colonialism. This fact is not something foreign to Islam. Since its inception, Islam has proven itself as an alternative force capable of changing every form of life that is not in accordance with human dignity, dignity and universal dictums.

Jawi Script was originally used to write the teachings conveyed by the preacher to his followers so that people who could not learn immediately could learn through the writings of the preachers. That in the process of civilized society's life, throughout its history, since the stone age until now, religion has seemed to support everything. So in terms of civilizing the community, it is the religion that holds the main function. (Uthman, 2010)

The script that used by the commentators of the al-Quran in Nusantara, targeting behavior and thought for the earthing of the 
values in the Holy Qur'an. It also reflects the influence of the sociocultural space where the interpretations were written. Interpretations written in the Aksara Jawi language generally appear in the Sumatra and Aceh regions; the authors were scholars who came from this region as well as in the era of the 17th and 18th centuries where Malay Jawi was a public communication tool at that time. Tarjumān alMustafid by 'Abd ar-Rauf as-Sinkili, which uses the Arabic language of Arabic script, certainly considers the situation of Muslims at that time, and the Jawi script is one of the dominant communication tools.

The use of Jawi in the Tafsir has several sociological reasons. First, language function factors. Jawi are accepted in society because they are not functionally bound to differences in the social level of society. This factor ensures that Jawi do not distinguish the social level of society, both the royal elite and the general public. So that the terminology of Islah Gusmian. (Gusmian, 2010) Jawi Tafsir spreads to the people of Nusantara based on the background of the social level of society contrary to the factors of the function of Jawi in the life of the Nusantara.

Examples of Abd Rauf As-Sinkili's interpretation on Tarjumān alMustafid about position of women in Surat al-Nisa ': 1, al-A 'raf: 189, and Az-Zumar: 6 does not at all interpret the origin of Eve (hawa) from the male ribs. Whereas in the same case the interpretation of Jalalayn, the interpretation of Khazin and Tafsir al-Baidhawi clearly revealed that Eve was created from Adam's left rib. (Syaifuddin, 2017) The election of Abd Rauf As-Sinkili not to interpret further about the creation of women, can be understood as an attempt to place women's position at the same level as men. This interpretation targets social behavior especially those related to the role of women's public. This 
point was raised because the ruler (Sultan) at that time was a woman. The position was a theme that was considered odd and continued to be questioned not only by religious leaders in Nusantara but also in several other parts of the Islamic world. This is an example of the involvement of the Qur'anic interpretation of the Jawi in the sociocultural transformation of Nusantara. Furthermore, this paper will examine the role of interpretation as one of the elements that plays a role in the cultural transformation of Nusantara. Especially transformation that is oriented towards people's thinking and behavior.

Second, the structure of language and script characters has a system that is easier than the Jawi. For example, the interpretation of Tarjumān al-Mustafìd explains the concept of tauhid. Tauhid conception is one of the concepts that is difficult to understand if it is explained in the structure of language that is too high. For changes in the theological mindset, this work will mainly focus on the issue of tauhid. Aside from being central to Islamic teachings, further translation of this concept led to problems such as wahdat al-wujud which also developed in Aceh at that time. Abd Rauf As-Sinkili also explained the concept of monotheism in an easy to understand language that targets changes in people's mindset and behavior.

Third, Jawi are simple and easy to accept outside influences. This was in the $17^{\text {th }}$ century $\mathrm{AD}$ for example, the famous Nusantara cleric was 'Abd ar-Rauf as-Sinkili (1615-1693). In fact, the print edition can be found in the Malay community, in a place as far as South Africa. The printed editions are not only published in Singapore, Penang, Jakarta and Bombay, but also in the Middle East. Tarjumān alMustafid is intended to provide a change of mindset and behavior of the people of Aceh at that time, there are 2 (two) mindsets and 
behaviors that are targeted namely; theological mindset and social behavior.

An anthropologist, Clifford Geertz, argues that religion is a cultural system that is influenced by various processes of social change and by itself can influence changes in cultural systems. (Geertz, 1988) Long before the arrival of the Nusantara religion Islam adhered to the beliefs of Animism and Dynamism. Both of them have very strong influence in the community. This belief is still carried out in a number of ways in several regions. The categories of cultural development in Nusantara can be seen according to the period of cultural predevelopment (animism and dynamism), the development of Hindu culture, the development of Buddhist culture, and the development of Islamic culture.

Throughout historical records mentioned that the spread of Islam in the Indonesian Nusantara is through tasawwuf (Putra, D.I. Ansusa, 2019) with a process that we often call Pacetique Penetration (peacefully). It can also be said that the spread of Islam in Indonesia is not based on a mission or an impulse of power, but the spread of Islam takes place slowly. Islam interacts with certain local cultures, there is a possibility that Islam will color, change, process, and even renew local culture, perhaps Islam which is colored by local culture.

Malay-Jawi manuscripts become important in the process of socio-cultural transformation of the Nusantara because it is a cultural heritage in the form of ancient writing that is priceless. The text contains various useful knowledge for life such as fiqh, tauhid, tasawuf, tajwid, history, law, advice and teaching instructions, medicine, hunches, dream veils, saga, syair, and nazam. (Syed Nuqaib Al-Attas, 1968) The knowledge produced is a science that reflects the 
wealth of Malay civilization thoughts and glories that need to be nurtured to benefit the present and future generations.(Ma'arif, 2007) The study of the Jawi script is intended to explore the role of Jawi literary interpretations in the socio-cultural transformation of Nusantara. Thus through these writings can be obtained a clearer picture of the mind, customs, beliefs, and value systems that apply to society in the past. It is very unlikely to be achieved if the information material only consists of material relics. That is, the legacy of a culture in the form of written manuscripts is the nation's most interesting document for researchers of old culture because it has advantages, namely being able to provide more extensive information compared to cultural heritage in other forms.

Understanding the relationship between the three major concepts (Culture, social change, and Islam, red), this paper would argue how culture, social change, and religion "communicate" so that they can explain the phenomena or symptoms observed in people's lives day byday. In anthropological studies, the transformation of cultural societies has different orientations. Viewed from the aspect of the transformation of the Nusantara culture, the writing of interpretations with Jawi script is oriented to the activities of the Nusantara community. Some interpretations of the Nusantara with the Jawi script in the 12 th to 17 th century illustrate that the purpose of interpretation targets changes in people's thinking and behavior. This orientation ensures the occurrence of socio-cultural transformation in the Nusantara. This is different from the writings of Islah Gusmian about Tafsir aksara Jawi. Islah Gusmian concluded that the use of jawi characters in interpretations is reader-oriented, not community 
behavior. (Gusmian, 2010) According to him, this orientation resulted in the term elitism or hierarchy among Nusantara interpreters.

\section{Conclusion}

The present study concludes that there is a close relationship between the stages (gradations) of Islamization of the Nusantara: Transmission, Formulation, and Transformation. Only a few experts identified these stages concerning Islamic scientific formulation. This paper attempts to fill the void by analyzing the indicators of Nusantara Islamic scientific formulation. The interpretation of the Tarjumān alMustafid contributes to studies of Quranic interpretations in the Nusantara and places the foundations for a bridge between transmitting and interpretations. According to vernacular theory, Anthony H. Johns that Tarjumān al-Mustafid had been written by Islamic vernacular this can be seen in three phenomena. First, the Arabic script in Malay is called the Jawi script. Second, the number of absorption words from Arabic that have been transformed into local languages. Third, many literary works were inspired by Arabic (and Persian) literary models. In addition, there is the absorption of linguistic and grammatical rules and structures in Arabic, such as words of al-Qisah and musyrik.

The interpretation of the Quran in Jawi terms is oriented to behavior and changes in the thinking of Nusantara people as in Weber's theory of the Sociology of Religion. Tarjumān al-Mustafid provides a thinking transformation about equality, humanity, and women's leadership based on a simple and acceptable theological concept in Nusantara society. 


\section{References}

Al-Attas, S. M. N. (1995). Prolegomena to the Metaphysics of Islam. In Kuala Lumpur: International Institute of Islamic Thought and Civilization.

Azra, A. (1992). The transmission of Islamic reformism to Indonesia: Networks of Middle Eastern and Malay-Indonesian "Ulama" in the seventeenth and eighteenth centuries. ProQuest Dissertations and Theses.

Azra, A. (1999). The transmission of al-Manar's reformism to the Malay-Indonesian world: The cases of al-Imam and al-Munir. Studia Islamika. https://doi.org/10.15408/sdi.v6i3.723

Fadil, S. (1990). Pengislaman Dunia Melayu: Transformasi Kemanusiaan dan Revolusi Kebudayaan.

Fakhriati, F. (2016). The Use of Papers in The Acehnese Islamic Manuscripts and its Historical Context. Heritage of Nusantara: International Journal of Religious Literature and Heritage. https://doi.org/10.31291/HN.V2I1.102

Fathurahman, O. (2014). Tradisi Intelektual Islam Melayu-Indonesia: Adaptasi dan Pembaharuan. Studia Islamika. https://doi.org/10.15408/sdi.v8i3.685 
Geertz, C. (1988). Interpretation of Cultures: Selected Essays by Clifford Geertz. Journal of Comparative Physiology $B$. https://doi.org/10.1007/BF00695328

Gusmian, I. (2010). Bahasa dan Aksara Tafsir Al-Qur'an di Indonesia. Jurnal Tsaqafah. https://doi.org/10.21111/tsaqafah.v6i1.136 Hasbullah, M. (n.d.). Islam \& transformasi masyarakat Nusantara: kajian sosiologis sejarah Indonesia.

JOHNS, A. H. (1998). THE QUR'AN IN THE MALAY WORLD: REFLECTIONS ON 'ABD AL-RA'UF OF SINGKEL (16151693). Journal of Islamic Studies. https://doi.org/10.1093/jis/9.2.120

KBBI. (2016). Kamus Besar Bahasa Indonesia ( KBBI ). In Kementerian Pendidikan dan Budaya.

Ma'arif, S. (2007). Sublimitas Indonesia. In Islam Nusantara: Pengaruh Keislaman dalam Sejarah Bangsa Indonesia. Pustaka.

Mustaqim, A. (2017). The epistemology of Javanese Qur'anic exegesis: A study of Sālih Darat's Fayd al-Rahmān. Al-Jami'ah. https://doi.org/10.14421/ajis.2017.552.357-390

Putra, D.I. Ansusa, A. R. (2019). Sufi Role in Transforming Nusantara Socio-Culture: Historical Reflections and Contemporary Discourse. Proceeding IAIN Batusangkar, Batusangkar International Conference.

Riddle, P. G. (2013). Islam and the Malay-Indonesian World: Transmission and Responses. In Dynamical systems with applications using MATLAB. https://doi.org/10.1017/CBO9781107415324.004

Rippin, A. (1988). The function of asbāb al-nuzūl in Qur 'ānic exegesis. Bulletin of the School of Oriental and African Studies. 
https://doi.org/10.1017/S0041977X00020188

Saeed, A. (2006). Islamic thought: An introduction. In Islamic Thought: An Introduction. https://doi.org/10.4324/9780203015247

Saenong, F. F. (2006). Vernacularization of the Qur'an: Tantangan dan Prospek Tafsir al-Qur'an di Indonesia, interview with A. H. John. Jurnal Studi Al-Qur'an, 1(3), 25-43.

Syaifuddin, W. (2017). Tafsir Nusantara. LKiS.

Syed Nuqaib Al-Attas. (1968). The Origin of The Malay Sha'ir.

Dewan Bahasa dan Pustaka.

Uthman, M. N. W. D. dan M. Z. (2010). The Correct Date of the Terengganu Inscription: Reconfirmed Using Astronomical Computer Programs. In Knowledge, Language, Thought and the Civilization of Islam: Essays in Honor of Syed Muhammad Naquib al-Attas. Universiti Teknologi Malaysia. 